\title{
Uganda's experience with debt and economic growth: an empirical analysis of the effect of public debt on economic growth-1980-2016
}

\author{
Richard Ssempala ${ }^{1 *}$, Kurayish Ssebulime $^{2}$ and Enoch Twinoburyo ${ }^{3}$
}

\section{${ }^{*}$ Correspondence:}

ssempala25@yahoo.com;

rssempala@musph.ac.ug

${ }^{1}$ Makerere University School

of Public Health, Kampala,

Uganda

Full list of author information is available at the end of the article

\begin{abstract}
Background: Empirical evidence on the effect of public debt on the economic growth of a country remains ambiguous. No theoretical convergence on the respective nexus has been attained. For the case of Uganda in particular, the public debt question remains critical in the country's development trajectory. Under the Highly Indebted Poor Countries (HIPCs) initiative, Uganda was the first country to receive a debt relief of worth US\$650 million in the 1990s and later in 2006, under the Multilateral Debt Relief Initiative (MDRI), the country generously received $100 \%$ debt forgiveness/cancelation which consequently reduced the stock of country's debt to $\$ 1.6$ billion. However, of recent, the debt stock has kept on increasing from UGX 14.257 trillion ( $\$ 5.5$ billion) in 2000 to the current UGX 35.3 trillion (9.8b) in July 2017 and it is projected to continue increasing in the short to medium term given the robust NDPII core projects and priorities which are set to attract more borrowing. The study employs the Auto Regressive Distributed Lag (ARDL)-bounds testing approach which is superior and suitable for our small sample.
\end{abstract}

Results: The results reveal that public debt has a significant negative impact on economic growth in short run whereas in long-run debt has a mixed impact on Uganda's economy. The total debt service has a negative impact whereas Gross debt as a share of GDP has a positive impact on the economy. The findings also reveal that Public debt has a negative effect on Uganda's economic growth in the short run. The impact is however found to be positive in the long run. This result is in line with the study expectations and some findings by earlier researchers who found a negative impact of public debt on GDP and investment. The results suggest that the current trend of Uganda's borrowing is to continue constraining the resources in the short run.

Conclusion: The conclusion of the study in view of emerging findings especially on debt, various policy implications have emerged. At the current rate of borrowing, Uganda is likely to have deteriorating economic growth partly because such public borrowing adversely affects investment. The study thus recommends for policies geared toward efficient use of borrowed funds especially for such projects that have high potential to unlock the production capabilities of the country. There is a need for 
the government of Uganda to institute mechanisms to ensure efficient use of borrowed funds.

Keywords: Auto-Regressive Distributed Lag (ARDL), Debt relief, Spurious results, Co-integration

\section{Introduction}

Most countries at one time borrow; this is usually because of the complexity and increased demand for better goods and services amidst changing roles of government and limited tax resources in relation to the planned public expenditures. Thus, while it is considered an optimal decision for governments to entirely rely on domestically generated revenues from taxes, public borrowing is at times sought to bridge the resource gap between tax revenues and expenditures (African Development Bank 2018).

Thus, governments while it is an optimal decision to entirely rely on domestically generated revenues from taxes, public borrowing is at times sought to bridge the resource gap between tax revenues and expenditures. However, this has trapped many emerging economies into debt syndrome. Countries seek funding from international communities through loans, grants and donations. Domestically the government seeks public funding through issuance of treasury bills and loans among other modes. Even though this endeavor increases resource availability, it is a contractual liability and has to be repaid.

In the context of this paper, public debt is defined as how much a country owes to lenders outside of itself. These can include individuals, businesses, and even other governments both internally and externally. It is usually divided into two; the external and domestic debt (Abbas and Christensen 2007). External public debt is the total public and private debt owed to nonresidents repayable in foreign currency, goods, or service. Government external debt is, therefore, the summation of current account deficit, increase in foreign exchange reserves and gross private short-term capital outflow less net longterm private capital inflow. Dereje (2013), however, defines external debt as that part of financial obligation in any national economy that is owed to a borrower outside the country; the borrowers can be a foreign country(s), International organizations, and corporations or private households.

On the other hand, Domestic Debt is the amount of money raised by the government, in local currency and from its own residents. Generally, domestic debt consists of two categories, which are Bank and Non-Bank borrowing. Domestic debt in Uganda has been mainly used to finance deficits and implement monetary policy in many African governments so that it now constitutes a large share of the total debt stock (AFRODAD African Forum et al. 2013).

Economic growth is defined as the total output (goods or services) produced by a country. In other words, it means an increase in the production capacity of the economy in terms of goods and services (Abbas 2005a, b). Economic growth occurs whenever people take resources and rearrange them in ways that are more valuable. Economic growth can be measured in nominal terms, which include inflation, or in real terms, which are adjusted for inflation, i.e., by the percent rate of increase in the gross domestic product (GDP). Economic growth measures growth in monetary terms and looks at no other aspects of development (Ayres and Warr 2002). 
In Uganda, economic growth has been relatively stable since the end of political instabilities in the 1980s. The government aspires to transform the economy from peasantry to middle-income status as indicated in the National Development plans I and II with optimal emphasis on infrastructure development in the form of roads, electricity and innovations. This has prompted the government to commit a lot of resources some of which have been solicited from foreign sources in the form of loans for such infrastructure.

Uganda's public and publically guaranteed external debt exposure as at end of December 2016, increased by $8.7 \%$ to US \$ 10.5 billions from 9.67 billion at the end of December 2015. Also, by end of December 2016, the total external service amounted to US \$ 69.3 million, of which $35.2 \%$ is principal repayments, $40.2 \%$ interest loan service and 24.6\% of commitments (MoFPED 2017).

Moreover for the years, the domestic debt has been increasing amidst little private sector credit. For instance, by December 2016, the total stock of outstanding debt stood at UGX 11,712 billion which is an equivalent of US \$ 3.25 billion. Uganda budgets for the last 3 Financial Years (FYs) are predominately occupied by huge payments to debt interest rates, taking a high percentage compared to other social development sectors like health, education water to mention but a few. For instance in then FY 2017/18, debt interest rates took $12.2 \%$ of the total budget (MoFPED 2017). Therefore, if the situation persists, this trend may plunge the country into a debt crisis. However, it is not clearly known how the rise in the country's public debt affects her economic growth especially for the case of Uganda. Thus, this study seeks to establish how the growth in public debt affects the country's economic growth.

This study is, therefore, a humble attempt to document the impact of public debt on Economic growth. Uganda has had a long history of debt. First, it was one of the countries to have benefited from HIPCs in the 1990s and MDRIS in which all her debts were canceled by $100 \%$. However, recently, the trend of public debt has been increasing at an exponential rate more than twice the rate at which the country got the debt reliefs. Debt and its structure have a great impact on the functioning of the economy as a whole, thus a better understanding of its impact on economic growth will influence better policies on the prudent use of borrowed resources where necessary.

\section{Overview of public debt and economic growth in uganda}

Uganda like many other developing countries has a long history of borrowing from both multilateral and bilateral countries. According to the BOU state of Economy reports for months, March, June and September, the trend of Uganda's debt has been increasing since last received debt relief in the 1990s and early 2005. Currently, the provisional total public debt stock (at the nominal value) at the end of May 2017 is estimated at Shs. 34.0 trillion, representing an increase of $14.1 \%$ as of June 2016 (BOU 2017). Figure 1 illustrates the trend of Uganda's debt 10 billions in the 1990s to the current 35.3 trillion.

In recognition of the need to address the debt burden of the low-income countries, international financial communities like the Paris club, creditors, non-Paris Club, bilateral and commercial creditor and multinational institution, Uganda qualified for the debt relief. Under this initiative, Uganda received an initial relief valued at US \$ 650 million in nominal value and an enhanced assistance valued at US \$ 1300 million 


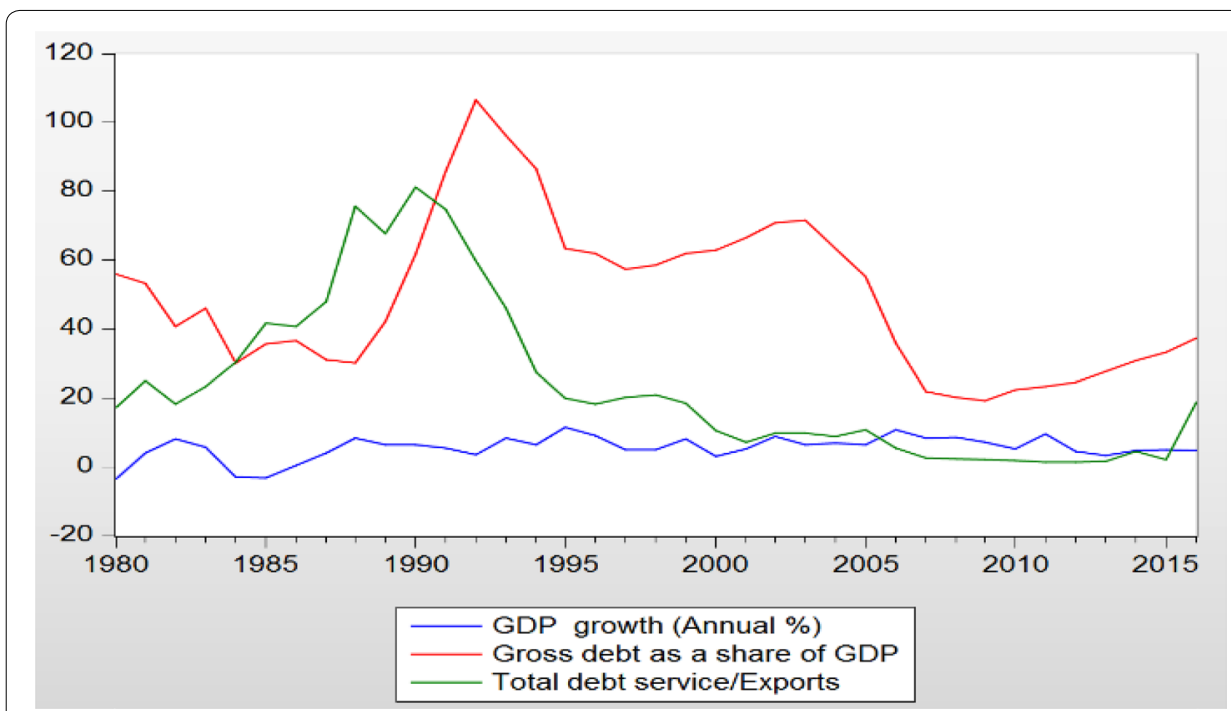

Fig. 1 Uganda's public debt in relation to debt to GDP, debt service to exports and GDP growth rate (Source: World Bank, 2015)

in nominal value. The HIPC initiative contributed to the reduction of the burden of external debt service from $15.54 \%$ in $2004 / 05$ to $13.1 \%$ in $2005 / 06$.

Later in 2005, the MDRI was again launched at the G8 summit in Scotland, where the G8 leaders pledged to cancel the debt of the world's most indebted poor countries. In this initiative, all debts of Uganda were canceled to $100 \%$ level for institutions like African Development Bank, The International Monetary Fund and the World Bank. Consequently, Uganda's external stock of debt was reduced by about $65 \%$. Figure 1 shows the trend of Uganda's debt specifically in terms of total debt to GDP, debt service to export in relation to the GDP growth rate.

It is indicated that the country's debt to GDP had hit more than $100 \%$ until when the HIPC initiative came in 1998. Uganda's economy, unlike other East African countries, has been expanding at an average rate of $7 \%$ per year in the last 20 years until recent in 2017 (Bank of Uganda 2017). The latest Real Gross Domestic Product (GDP) growth data released by the Uganda Bureau of Statistics (UBOS) estimated the economy to grow by $3.9 \%$ in $2016 / 17,0.6$ points lower than the period revised projection of $4.5 \%$ and 0.8 points lower than the outturn for FY 2015/16 of $4.7 \%$. The poverty level though has been steadily reducing over years; it has remained significantly high especially in northern and eastern part of the country (Oxfam 2016). Figure 2 shows Uganda's economic growth from 1980 to 2016

Figure 2 illustrates the trend of Uganda's growth from negative figures in the early 1980 s to current seemly good progress. The negative trend was basically caused by political instabilities which the country experienced until when the National Resistance movement government took over power in 1986. In terms of policies, Uganda has in place sound legislative and policy framework for the management of public debt and Private-Public Partnerships. These include the 2015 Public Finance Management Act, Medium Term Debt Management Strategy 2015/16-2019/20, the 2013 Public Debt management framework, PPP policy and the 2015 PPP Act. All these 

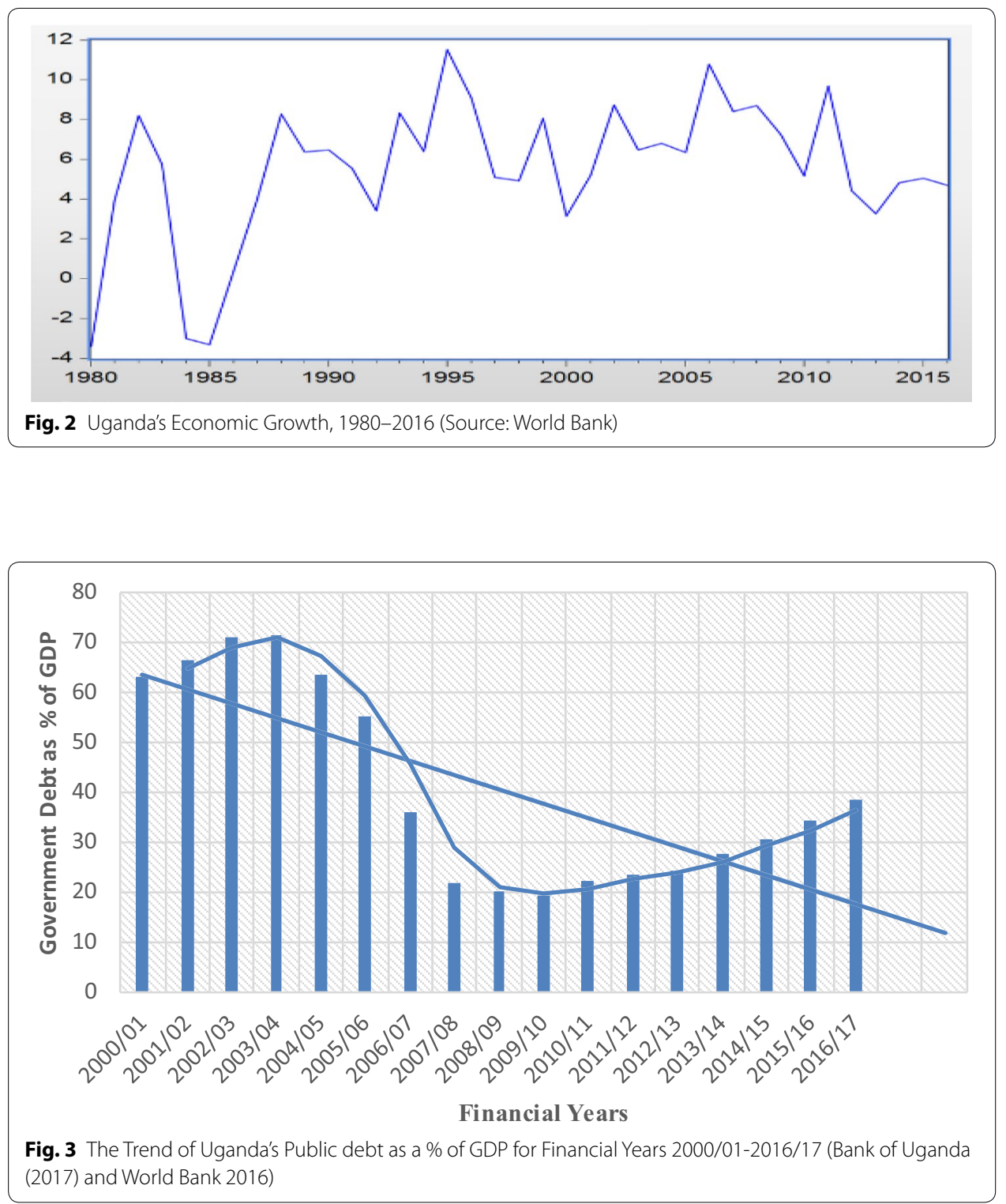

policies are put in place for the proper management of a country's debt. However, the trend of Uganda debt is most likely to resemble that of the 1990s when the country sought debt forgiveness under the Highly Indebted Poor Countries initiative (Fig. 3).

According to the first and second National Development plans, the government is so committed to addressing infrastructural constraints by constructing and rehabilitation of roads, railways, airports and Dams. This is to be done largely through externally generated resources in the form of loans. Sadly, this epoch has coincided with low absorption capacities of the available resources and slowdown in the GDP growth has been encountered reaching about 5\% in FY 2014/15 in FY 2015/16.

Uganda's debt has been mainly driven by ambitious targets as stipulated in both the Second National Development Plan (NDP II) and Vision 2040 aimed at transforming 
from Uganda from the peasantry to lower-middle-income status by 2020, then to a upper-middle-income category by 2032 and attaining per capita incomes of USD 9500 in 2040 (National Planning Authority (NPA) 2010). Achieving these targets thus have propelled the government to invest in tremendous infrastructural such as dams, railways, and airports basically to unlock the productivity of physical and human capital.

\section{Literature review}

The theoretical literature on the relationship between public debt and economic growth tends to point to a negative relationship. Growth models augmented with public agents issuing debt to finance consumption or capital goods tend to exhibit a negative relationship between public debt and economic growth, particularly in a neoclassical setting.

Modigliani (1961), refining contributions by Buchanan (1958) and Meade (1958), argued that the national debt is a burden for the next generations, which comes in the form of a reduced flow of income from a lower stock of private capital. Apart from a direct crowding-out effect, he also pointed out to the impact on long-term interest rates, possibly in a non-linear form "if the government operation is of sizable proportions it may significantly drive up [long-term] interest rates since the reduction of private capital will tend to increase its marginal product" (p. 739). Even when the national debt is generated as a counter-cyclical measure and "in spite of the easiest possible monetary policy with the whole structure of interest rates reduced to its lowest feasible level" (p. 753), the debt increase will generally not be costless for future generations despite being advantageous to the current generation.

Modigliani considered that a situation in which the gross burden of national debt may be offset in part or in total is when debt finances government expenditure that could contribute to the real income of future generations, such as productive public capital formation. Diamond (1965) adds the effect of taxes on the capital stock and differentiates between public external and internal debt. He concludes that, through the impact of taxes needed to finance the interest payments, both types of public debt reduce the available lifetime consumption of taxpayers, as well as their saving, and thus the capital stock. In addition, he contends that internal debt can produce a further reduction in the capital stock arising from the substitution of government debt for physical capital in individual portfolios.

Adam and Bevan (2005) find interaction effects between deficits and debt stocks, with high debt stocks exacerbating the adverse consequences of high deficits. In a simple theoretical model integrating the government budget constraint and debt financing, they find that an increase in productive government expenditure, financed out of a rise in the tax rate, will be growth-enhancing only if the level of (domestic) public debt is sufficiently low. An important channel through which public debt accumulation can affect growth is that of long-term interest rates. Higher long-term interest rates, resulting from more debt-financed government budget deficits, can crowd-out private investment, thus dampening potential output growth. Indeed, if higher public financing needs to push up sovereign debt yields, this may induce an increased net flow of funds out of the private sector into the public sector.

This may lead to an increase in private interest rates and a decrease in private spending growth, both by households and firms (see Elmendorf 1999). While the empirical 
findings on the relationship between public debt and long-term interest rates are diverse, a significant number of recent studies suggest that high debt and deficits may contribute to rising sovereign long-term interest rates and yield spreads. In Krugman's specification, the external debt overhang affects economic growth through private investment, as both domestic and foreign investors are deterred from supplying further capital. Other channels may be total factor productivity, as proposed in Pattillo (2002), or increased uncertainty about future policy decisions, with a negative impact on investment and further on growth, as in Agénor and Montiel (1996) and in line with the literature of partly irreversible decision-making under uncertainty (Dixit and Pindyck 1994).

Hassan and Akhter (2012) in their study on public debt and economic growth in Bangladesh for the period 1980-2012 found out that there was no strong statistical evidence regarding the negative impact of external debt on the GDP growth. The study used the augmented Dickey-Fuller test, Johansen co-integration test, and error correction model and vector error collection model for this analysis. The study further revealed that there exists a significant positive relationship between total public debt and investment, and between total public debt and government's reserves. On the other hand, a negative relationship exists with the manufacturing sector and government subsidy. However, no strong statistical evidence was found regarding the negative impact of external debt on GDP growth. But with domestic debt, it was found negatively related to GDP with little statistical significance.

Cecchetti et al. (2010) study shows that in cases of increased public debt, there is a high possibility of negative sustained economic growth and an unstable economic environment. In addition, Kumar (2010) further elucidates that a persistently high level of public debt can consequently trigger detrimental effects on capital accumulation and productivity which potentially has a negative impact on economic growth. They found that between $85 \%$ and $100 \%$, a debt brings in a deleterious effect on the country's economic growth. They stress that this is manifested through different channels like higher long-term interest rates, higher distortionary taxation, higher inflation and greater uncertainty and vulnerability to crises.

Muinga (2014) conducted a study to examine the relationship between external public indebtedness and economic growth in Kenya. She used the Augmented Dickey-Fuller Unit Root test for ascertaining stationarity and used the OLS method in data analysis. The study used data from 1970 to 2010 from World Bank and the results indicated that external debt and interest payments on external debt payments contribute negatively to economic growth in Kenya and the simulation results showed that any percentage increase of external debt holding other factors constant will reduce the GDP hence slow economic growth. The study recommended that the policies of debt management in Kenya be reviewed and improved.

Chongo (2013) conducted a study to analyze the impact of increasing public debt on Zambia's economic growth covering the period 1980 to 2008 and the study analyzed channels through which public debt is said to have an impact on economic growth namely through private investment, public investment and domestic saving. The vector error correction model approach was employed and the results from the analysis confirmed a long-run negative relationship between public debt and economic growth. The study recommended that the government should put in place a public debt law to rectify 
any borrowing requirements hence this would help in ensuring that all borrowing by the government is targeted toward the financing of projects that have a high return which would result in crowding in of private investments well as ensure fiscal sustainability.

What is noted in the reviewed studies is that the direction of the impact/effect of public debt on economic growth is not clear, some studies portray increased public debt as a menace to development see Hassan (2012), Cecchetti et al. (2010) and El-Mahdy and Adel (1999), whereas others appreciate its role in boosting economic growth especially at some level (Burhanudin et al. 2017). For the case of Uganda, no empirical evidence is yet provided. Thus, this study intends to estimate the short-run and the long-run effect of the public on Uganda's economic growth.

\section{Methodology and data sources}

\subsection{Theoretical framework}

To model the effect of public debt on economic growth of Uganda, we adopt the endogenous growth model which argues that economic growth is generated from within a system as a direct result of internal processes. To do this, we extend a model modified by Casadio et al. (2012) who estimated the steady-state growth rates for some European countries. In this model, Casadio et al. (2012) start with the following Cobb-Douglas production function in per capita terms:

$$
g_{t}=A_{t} k_{t}^{\beta} .
$$

Expressing growth rate of Gross Domestic Product, Labor and Capital in per capita terms implies that

$$
g_{t}=\frac{G_{t}}{L_{t}}, \quad k_{t}=\frac{K_{t}}{L_{t}}
$$

Casadio et al. (2012) assume that

$$
A_{t}=A_{0} e^{g_{A} t} .
$$

According to Casadio et al. (2012), $g_{A}$ is the growth rate of technology. According to the Solow growth model, the growth rate of technology grows exogenously yet according to the endogenous growth model; the growth rate of technology can be affected by some variables that are associated with technology transfer, research and development, and other policies' choices such as the level of public debt technology transfer (Dasgupta 2010).

The effect of public debt on economic growth thus enters the endogenous growth theory as a policy variable that affects the rate of technology growth. This modification of the endogenous growth theory is in line with Casadio et al. (2012). The growth rate of technology is endogenous, since increased saving propensity affects its time path. Based on these findings, technology growth rate is written as

$$
g_{A}=\frac{\dot{A}}{A}=\delta_{0}+\delta_{1} V
$$


From Eq. (4), $V$ is a vector of the factors that can affect technological growth rate such as public debt and other macro-economic variables. Therefore, combining Eqs. (4) and (5), we obtain Eq. 5 as below:

$$
A_{t}=A_{0} e^{\left(\delta_{0}+\delta_{1} v\right) t}
$$

Combining Eqs. (5) and (2), we yield Eq. (6) as below:

$$
A_{t}=A_{0} e^{\left(\delta_{0}+\delta_{1} v\right) t} k_{t}^{\beta} .
$$

Taking logarithm and differentiating both sides with respect to time $(t)$, we have

$$
\begin{aligned}
& \ln g_{t}=\ln A_{0}+\delta_{0} t+\delta_{1} Z t+\beta \ln k_{t}, \\
& \Delta \ln g_{t}=\delta_{0}+\delta_{1} Z t+\beta \Delta \ln k_{t} .
\end{aligned}
$$

At the steady state, assuming that $\Delta \ln k_{t}=0$, it implies that the steady-state growth rate of per capita output is determined by the growth rate of technological progress, which is affected by some other variables.

$$
\Delta \ln \dot{g}=\delta_{0}+\delta_{1} \dot{Z}
$$

Equation (9) indicates that the steady-state growth rate of gross domestic product is a function of the variables that are influenced by economic policies and forms the basis of our estimation in this paper. Estimating this Eq. (9) and also control for unauthentic findings also known as spurious results, it is essential that $\Delta \ln g$ and $Z$ are stationary. This implies that the choice of $Z$ is important. In many cases, $Z$ represents a set of the variables such as public debt, trade openness, real interest rates, trade openness, capital formation, debt service, inflation among others that affect the growth rate of output. As earlier presented, we note that the effect of public debt on economic growth could be affected by the level of macro-economic stability. Therefore, to complete our model for estimating the effect of public debt on economic growth, we include the interaction term between public debt and inflation rate as an indicator for macro-economic stability.

\subsection{Data}

Data employed in this study cover the period from 1980 to 2016. The World Development Indicators (WDI) provided invaluable statistical data for most of the macro-economic variables invoked see Table 1 . There was a preference for statistical data from the WDI given the inconsistency of the data in Uganda on some of the key variables from the Ministry of Finance Planning and Economic Development and Bank of Uganda especially on debt. For some variables, however, there are one or two missing values but since the time frame is too long, the effects of such variables are mitigated given the fact that the time series of 1980 to 2016 is adequate enough to capture any data lapses (Table 1). 
Table 1 Definition of variables and sources of data

\begin{tabular}{|c|c|c|}
\hline Variable and symbol & Definition & Source of data on variable \\
\hline GDP growth (GDP) & $\begin{array}{l}\text { Growth in gross domestic } \\
\text { Product measured in percentages. }\end{array}$ & World Bank \\
\hline Real Interest Rates (RIR) & $\begin{array}{l}\text { This is the lending interest rate adjusted } \\
\text { for inflation as measured by the GDP } \\
\text { deflator }\end{array}$ & World Bank \\
\hline Trade Openness (TO) & $\begin{array}{l}\text { This study used the sum of exports and } \\
\text { imports to GDP ratio as a proxy for } \\
\text { trade openness }\end{array}$ & World Bank and Bank of Uganda \\
\hline Debt-to-GDP Ratio (DEBT_G) & $\begin{array}{l}\text { The ratio of a country's gross public debt } \\
\text { to its gross domestic product }\end{array}$ & World Bank \\
\hline Human capital Development (HC) & $\begin{array}{l}\text { This is the ability to perform labor to pro- } \\
\text { duce economic value (proxied by gross } \\
\text { secondary school enrollment rate) }\end{array}$ & World bank \\
\hline Population growth rate (POPN_G) & $\begin{array}{l}\text { This is the rate at which the number of } \\
\text { individuals in a population increases } \\
\text { in a given time period, expressed as a } \\
\text { fraction of the initial population }\end{array}$ & World bank \\
\hline Gross capital formation (K-Fm) & $\begin{array}{l}\text { It consists of outlays on additions to the } \\
\text { fixed assets of the economy plus net } \\
\text { changes in the level of inventories }\end{array}$ & World Bank \\
\hline Total debt service/Exports (DEBT_X) & $\begin{array}{l}\text { The debt service ratio is the ratio of debt } \\
\text { service payments made by or due } \\
\text { from a country to that country's export } \\
\text { earnings }\end{array}$ & World bank \\
\hline
\end{tabular}

\subsection{Estimation techniques and models}

\subsubsection{Unit root test}

In time series analysis, before running the casualty test, the variables must be tested for stationarity (Gujarati 1995). This is because the use of non-stationary data may lead to spurious results and any interpretation made based on such results becomes meaningless. A random time series Yt is said to be stationary if its mean and variance are constant over time and the value of covariance between two time periods depends only on the distance between the two time periods and not on the actual time at which the variance is computed (Gujarati 1995. For this purpose, therefore, the study used Augmented Dickey-Fuller (ADF) unit root test to check whether the variables are non-stationary by taking the null hypothesis as 'there is the unit root' against the alternative hypothesis 'there is no unit root'.

\subsubsection{Co-integration test}

Even though the individual time series are not stationary, a linear combination of these variables could be co-integrated. The study thus used the Peserani/Shin ARDL (bound test) approach to co-integration test, rather than the other co-integration test techniques (Engle-Granger \& Johansen's procedure). Due to the low power and other problems associated with these test methods, the OLS-based autoregressive distributed lag (ARDL) approach to co-integration has become popular in recent years. The main advantage of ARDL modeling lies in its flexibility that it can be applied when the variables are of a different order of integration (Pesaran and Shin 1997). Another advantage of this approach is that the model takes sufficient numbers of lags to capture the data-generating process 
in a general-to-specific modeling framework (Laurenceson and Chai 2003). Moreover, a dynamic error correction model (ECM) can be derived from ARDL through a simple linear transformation (Banerjee et al. 1993). In addition, the ECM integrates the short-run dynamics with the long-run equilibrium without losing long-run information. It is also argued that using the ARDL approach avoids problems resulting from non-stationary time series data (Laurenceson and Chai 2003).

\subsection{Empirical Model for estimation}

From the model developed in xi, and also following Mankiw et al. (1992), paper on "A Contribution to the Empirics of Economic Growth", the standard growth model is augmented with variables like public debt; trade openness to assess the impact of public debt on growth economic growth model is presented in Eq. (10):

$$
\mathrm{GDP}=f\left(\mathrm{DEBT} \_\mathrm{G}, \mathrm{RIR}, \mathrm{TO}, \mathrm{HC}, \mathrm{POPN}, \mathrm{K} \_\mathrm{F}\right. \text {, and DEBT_X) }
$$

where GDP: economic growth; RIR: Real Interest Rate; TO: Trade Openness; HC: Human capital; POPN: Population growth rate; DEBT_G: Gross debt as a share of GDP; K_F: Gross capital formation; INF: Inflation, and DEBT_X: Total debt service/Exports. Econometric expression: Once it is was verified that none of the variables were I(2), the following ARDL Model of Economic growth was estimated:

$$
\begin{aligned}
\mathrm{GDP}_{t}= & \beta_{0}+\beta_{1} \mathrm{GDP}_{t-1}+\beta_{2} \mathrm{DEBT}_{-} \mathrm{G}_{t-1}+\beta_{3} \mathrm{~K}_{-} \mathrm{F}_{t-1}+\beta_{4} \mathrm{TO}_{t-1}+\beta_{5} \mathrm{RIR}_{t-1} \\
& +\beta_{6} \mathrm{HC}_{t-1}+\beta_{7} \mathrm{POPN}_{t-1}+\beta_{8} \mathrm{INF}_{t-1}+\beta_{9} \mathrm{DEBT} X_{t-1}+\sum_{i=1}^{n} \partial_{1} \Delta(\mathrm{GDP})_{t-1} \\
& +\sum_{i=0}^{n} \partial_{2} \Delta\left(\mathrm{DEBT} \mathrm{C}_{t-1}+\sum_{i=1}^{n} \partial_{3} \Delta\left(\mathrm{K}_{-} \mathrm{F}\right)_{t-1}+\sum_{i=0}^{n} \partial_{4} \Delta(\mathrm{TO})_{t-1}\right. \\
& +\sum_{i=0}^{n} \partial_{5} \Delta(\mathrm{RIR})_{t-1}+\sum_{i=0}^{n} \partial_{6} \Delta(\mathrm{HC})_{t-1}+\sum_{i=0}^{n} \partial_{7} \Delta(\mathrm{POPN})_{t-1} \\
& +\sum_{i=0}^{n} \partial_{8} \Delta(\mathrm{INF})_{t-1}+\sum_{i=0}^{n} \partial_{9} \Delta\left(\mathrm{DEBT} \_\mathrm{X}\right)_{t-1}+u_{t} .
\end{aligned}
$$

All variables are estimated in percentages. In addition, $u_{t}, \beta, \partial$ and $t$ are respectively the white-noise error term, the short-run coefficients and the long-run coefficients of the model. $\Delta$ is the first difference operator, $t$ denotes time period, and $n$ is the maximum number of lags in the model. This model is estimated using EVIEWS and the maximum lag of each regressor $(k)$ is detained by minimizing the Akaike Information Criteria.

\section{Empirical estimation and results}

\subsection{Descriptive statistics}

The major variables of interest in this study are economic growth (GDP), Real Interest Rate (RIR), Trade Openness (TO) Human capital (HC), Population growth rate (POPN) Gross debt as a share of GDP (DEBT_G), Gross capital formation (K_F), Inflation (INF) and Total debt service/Exports (DEBT_X)

The summary statistics in Table 2 reveal some key characteristics of the variables. It is shown that all variables have the same number of observations. Almost all the variables 
have non-zero standard deviations with a maximum from inflation and the minimum from population growth rate. Time series data must be tested for stationarity before running ARDL co-integration tests to determine their order of integration. The presence of I(2) variables renders the ARDL inappropriate (Ouattara 2004). Table 3 provides the results of $\mathrm{ADF}$ (Augmented Dickey-Fuller) test results. It is revealed that all variables are stationary after the first difference.

The unit root test results reported in Table 3 reveal that all variables are integrated of order zero and one, supporting the application of the ARDL bounds testing approach to co-integration in this study. The bounds testing procedure is carried out by conducting the $\mathrm{F}$ test for the joint significance of coefficients of the lagged variables. In this, the null hypothesis of no co-integration is tested against the alternative hypothesis of co-integration. According to Pesaran et al. (2001), the null hypothesis of no co-integration is rejected if and only if when the calculated F-statistic is greater than the upper-bound values. However, the test is inconclusive when the F-statistic falls between the lower and upper bounds. The Akaike Information Criteria (AIC) and Schwartz-Bayesian Criteria (SBC) are used for the ARDL model lag length selection (Pesaran and Shin 1995). Since we have only 37 observations, with 7 parameters, Pesaran et al. (2001) suggest that for such short observations, a maximum lag length of 2 is sufficient. This is done using the $F_{-}$test and results are presented in Table 4.

Table 2 Summary of descriptive statistics of the variables

\begin{tabular}{llccll}
\hline Variable & Obs & Mean & Std. Dev. & Min & Max \\
\hline GDP & 37 & 5.535676 & 3.496244 & -3.4 & 11.52 \\
RIR & 37 & 0.2208107 & 21.75185 & -53.44 & 23 \\
TO & 37 & 36.69297 & 9.328611 & 22.3 & 56.26 \\
HC & 37 & 16.03676 & 7.760305 & 5.19 & 30 \\
POPN & 37 & 3.236757 & 0.154003 & 2.98 & 3.51 \\
DEBT_G & 37 & 54.83405 & 35.54099 & 19.2 & 220.3 \\
K_F & 37 & 17.49784 & 6.901355 & 5.6 & 28.22 \\
INF & 37 & 37.14649 & 56.43211 & -0.29 & 200.03 \\
DEBT_X & 37 & 23.66865 & 23.29098 & 1.36 & 81.36 \\
\hline
\end{tabular}

Sources: Authors' computation

Table 3 The augmented Dickey-Fuller test results for stationarity (Unit roots test)

\begin{tabular}{|c|c|c|c|c|c|}
\hline \multirow[t]{2}{*}{ Variable } & \multirow{2}{*}{$\begin{array}{l}\text { Stationarity (levels) } \\
\text { No trend }\end{array}$} & \multirow{2}{*}{$\begin{array}{l}\text { Stationarity (1st } \\
\text { differences) } \\
\text { With trend }\end{array}$} & \multirow[b]{2}{*}{ No trend } & \multirow[b]{2}{*}{ With Trend } & \multirow[t]{2}{*}{ Status } \\
\hline & & & & & \\
\hline GDP & $-4.20^{* *}$ & & - & $\mathrm{I}(0)$ & $\mid(0)$ \\
\hline DEBT_G & $-5.361^{* * *}$ & & & & $\mid(0)$ \\
\hline K_F & - & $-4.46^{* *}$ & - & - & $\mid(1)$ \\
\hline TO & - & & & $-4.44^{* *}$ & $\mid(1)$ \\
\hline $\mathrm{RIR}$ & - & - & $-6.733^{* * *}$ & - & $\mid(1)$ \\
\hline $\mathrm{HC}$ & - & - & $-5.29 * * *$ & & $\mid(1)$ \\
\hline POPN & - & - & $-4.24^{* *}$ & & $\mid(1)$ \\
\hline INF & - & - & - & $-3.87^{*}$ & $\mid(1)$ \\
\hline DEBT_X & - & - & - & $-4.44^{* *}$ & $\mid(1)$ \\
\hline
\end{tabular}

$p$ values of coefficients: ${ }^{* * *} p<0.01,{ }^{* *} p<0.05$ and ${ }^{*} p<0.1$ 


\subsection{Bound $F$ test results}

\subsubsection{Author's computation}

Since the computed $F$ value of $\mathbf{1 3 . 7 3 6 3 3}$ (Table 4) exceeds the upper bound critical values at all levels of significance, this depicts that there exists a co-integrating relationship among the variables. This thus guarantees the use of the ARDL approach in establishing the short- and long-run effects of variables on economic growth (see Table 5 for details).

\subsubsection{Diagnostic tests}

See Tables 5 and 6.

Table 4 Bound $\boldsymbol{F}$ test results

\begin{tabular}{llll}
\hline F-statistic value & Significance level & \multicolumn{2}{l}{ Bound critical values } \\
\cline { 3 - 4 } & & $\mathbf{1 ( 0 )}$ & $\mathbf{1 ( 1 )}$ \\
\hline $\mathbf{1 3 . 7 3 6 3 3}$ & $10 \%$ & 1.85 & 2.85 \\
& $5 \%$ & 2.11 & 3.15 \\
& $2.5 \%$ & 2.33 & 3.42 \\
& $1 \%$ & 2.62 & 3.77 \\
\hline
\end{tabular}

Table 5 ARDL estimation results for the effects of public debt on economic growth

\begin{tabular}{lcccc}
\hline Variable & Coefficient & Std. Error & t-statistic & Prob. \\
\hline GDP(-1) & -0.339797 & 0.168359 & -2.018292 & 0.0665 \\
GDP(-2) & -0.413285 & 0.159785 & -2.586499 & 0.0238 \\
K_FM & 0.280336 & 0.211622 & 1.324701 & 0.2099 \\
DEBT_X & 0.175702 & 0.067054 & 2.620317 & 0.0224 \\
DEBT_X(-1) & -0.368388 & 0.064249 & -5.73378 & 0.0001 \\
DEBT_X(-2) & 0.075324 & 0.05066 & 1.486865 & 0.1628 \\
DEBT_G & -0.002437 & 0.010926 & -0.223078 & 0.8272 \\
DEBT_G(-1) & 0.033349 & 0.011422 & 2.919792 & 0.0128 \\
DEBT_G(-2) & 0.010767 & 0.010746 & 1.001917 & 0.3362 \\
HC & -0.033936 & 0.262736 & -0.129163 & 0.8994 \\
HC(-1) & -0.26643 & 0.315824 & -0.843603 & 0.4154 \\
HC(-2) & -0.419126 & 0.255302 & -1.641684 & 0.1266 \\
INF & -0.081963 & 0.023634 & -3.468031 & 0.0046 \\
INF(-1) & 0.087399 & 0.021436 & 4.077226 & 0.0015 \\
POPN & -36.92111 & 15.0362 & -2.455482 & 0.0303 \\
POPN(-1) & 52.46615 & 13.93491 & 3.765089 & 0.0027 \\
RIR & -0.071603 & 0.066832 & -1.071394 & 0.3051 \\
RIR(-1) & 0.175266 & 0.050256 & 3.487462 & 0.0045 \\
RIR(-2) & -0.036471 & 0.03601 & -1.012791 & 0.3311 \\
TRADE_O & 0.609176 & 0.160858 & 3.787053 & 0.0026 \\
TRADE_O(-1) & -0.697222 & 0.177752 & -3.92245 & 0.002 \\
TRADE_O(-2) & 0.257874 & 0.137533 & 1.874992 & 0.0853 \\
C & -39.94619 & 21.318 & -1.873825 & 0.0855 \\
\hline & & & \\
\hline
\end{tabular}


Table 6 Model statistics

\begin{tabular}{lll}
\hline R-squared & $\mathbf{0 . 9 2 5 0 2 0}$ Mean-dependent var & $\mathbf{5 . 8 3 8 9 3}$ \\
\hline Adjusted R-squared & 0.787558 S.D.-dependent var & 3.22857 \\
S.E. of regression & 1.488094 Akaike info criterion & 3.87671 \\
Sum squared resid & 26.57310 Schwarz criterion & 4.8988 \\
Log-likelihood & -44.84250 Hannan-Quinn criteria & 4.229538 \\
F-statistic & 6.729244 Durbin-Watson stat & 2.82375 \\
Prob(F-statistic) & 0.000736 & \\
\hline
\end{tabular}

The $R$-square of 0.925 and the $F$-statistic of 6.729 for model significance imply that the regressors in the model are adequately able to explain public debt and its effect on Uganda's economic growth (see Table 6)

\subsubsection{Stability test}

The cumulative sums (CUSUM) graphs in Fig. 4 show that the coefficient of the shortrun lies within the critical limits and indicates stability in the coefficients over the sample period (Fig. 5).

These results indicate that the estimated ADRL Model has passed the major econometric diagnostic tests and thus the results are not being affected by heteroscedasticity or autocorrelation. The R-square of 0.925020 and the F-statistic of 6.729244 for model significance imply that the regressors in the model are adequately able to explain economic growth. To establish the short-run effects of different regressors on economic growth, an Error Correction Model was run and the results are as presented in Table 8. The long run results for themodel are as well presented in Table 9.

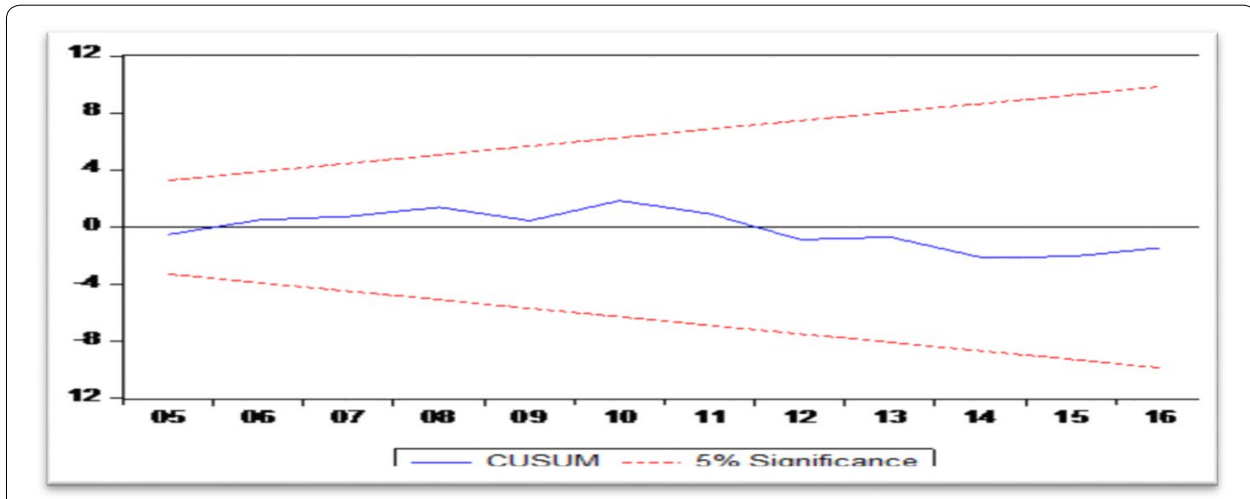

Fig. 4 Plot of the cumulative sum of recursive residuals

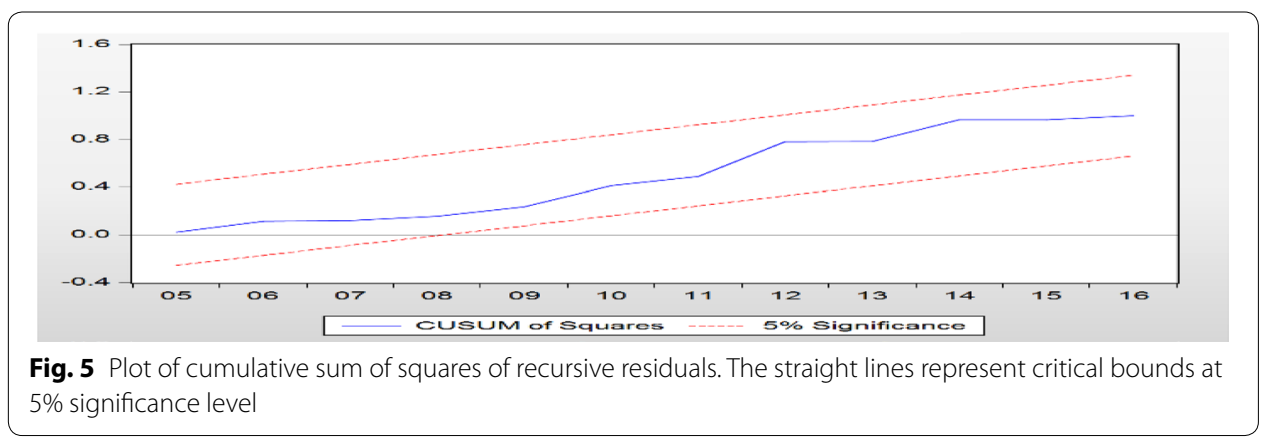




\section{Discussion of results}

Tables 7 and 8 reveal that in the short-run public debt as proxied by both Gross debts as a share of GDP and Total debt service/Exports has a negative impact on Uganda's economic growth. This is because Gross debt as a share of GDP and Total debt service/ Exports are all significant and possess negative coefficient signs. The results suggest that the current trend of Uganda's borrowing is to continue constraining the resources in the short run. This result is in line with Naeem Akrah's study in Pakistan who found a negative impact of public debt on GDP and investment.

The analysis, in addition, reveals that population growth rate, real interest rate, Trade openness, and inflation are significant and negatively affect economic growth in the short run. The results reveal further that Human capital development as proxies by enrollment in secondary school has a positive and significant impact on Uganda's economic growth. In addition, the results from the error correction model imply that Uganda's economic growth is stable and has a long-run equilibrium. This is because the error correction term $\operatorname{ECM}(-1)$ is both statistically significant and negative. Furthermore, since the coefficient of the error correction term is -1.753081 , it can be inferred that, when economic growth deviates from its long-run equilibrium path, there exists a rapid correction mechanism that will correct the growth path back to equilibrium within 1 year. Thus, its take less than 1 year for Uganda's economy to fully stabilize after a sudden disturbance attributed to either external or internal factors (Table 9).

The long-run results as presented in Tables 5 and 7 show that the coefficients of debt to GDP ratio, Human capital, and Population growth rate are positive and statistically significant, suggesting a positive impact on economic growth. However, the coefficient of Trade openness, Capital formation, Real interest rate, and inflation are positive and statistically insignificant. It is only the Total debt service/Exports which is statically negative in the long run.

Table 7 Diagnostic test results performed on the ARDL model

\begin{tabular}{llll}
\hline Test for: & Diagnostic Test & $\boldsymbol{p}$ values & Status \\
\hline Heteroscedasticity & Breusch-Pagan-Godfrey Test & $0.495122(0.9263)$ & No Heteroskedasticity \\
Goodness of Fit & R-Square Test & 0.925020 & Model fits data well \\
Normality & Jarque-Bera Test & $1.24588(0.536365)$ & Residuals are normal \\
\hline
\end{tabular}

Table 8 Summary of the error correction model results (short run)

\begin{tabular}{lcccc}
\hline Variable & Coefficient & Std. Error & $\boldsymbol{t}$-statistic & Prob. \\
\hline D(GDP(-1) & $0.413285^{* * *}$ & 0.07923 & 5.216101 & 0.0002 \\
D(DEBT_X(-1) & $-0.07534^{* *}$ & 0.02865 & -2.62881 & 0.022 \\
D(DEBT_G(-1) & $-0.010767^{* *}$ & 0.00565 & -1.90578 & 0.0809 \\
D(HC(-1) & $0.41916^{* *}$ & 0.14634 & 2.863999 & 0.0142 \\
D(INF) & $-0.081963^{* * *}$ & 0.01103 & -7.42966 & 0 \\
D(POPN) & $-36.92111^{* * *}$ & 6.49881 & -5.68121 & 0.0001 \\
D(RIR) & $-0.071603^{* *}$ & 0.02707 & -2.64543 & 0.0214 \\
D(TO(-1)) & $-0.257874^{* *}$ & 0.06539 & -3.94364 & 0.002 \\
ECT(-1)* & -1.753081 & 0.11307 & -15.5044 & 0 \\
\hline
\end{tabular}


Table 9 Summary of the error correction model (long run)

\begin{tabular}{lcccc}
\hline Variable & Coefficient & Std. Error & t-statistic & Prob. \\
\hline K_F & 0.15991 & 0.11584 & 1.380423 & 0.1926 \\
DEBT_X & $-0.066946^{* *}$ & 0.02386 & -2.8064 & 0.0159 \\
DEBT_G & $0.023774^{* *}$ & 0.01207 & 1.969853 & 0.0724 \\
HC & $-0.410415^{* *}$ & 0.16293 & -2.519 & 0.027 \\
INF & 0.003101 & 0.01867 & 0.16607 & 0.8709 \\
POPN & $8.867269^{* *}$ & 3.94448 & 2.248021 & 0.0442 \\
RIR & 0.038328 & 0.04647 & 0.824756 & 0.4256 \\
TO & 0.096874 & 0.11531 & 0.840129 & 0.4173 \\
C & -22.78627 & 13.0573 & -1.7451 & 0.1065 \\
\hline
\end{tabular}

\section{Conclusions and policy implications}

The study examines the effects of public debt on economic growth in Uganda. The study uses the ARDL model on annual data for different variables. It is revealed that public debt has a significant negative impact on economic growth in short run whereas in longrun debt has a mixed impact the economy; that is, Total debt service/Exports has a negative impact whereas Gross debt as a share of GDP has a positive impact on the economy. Keeping in view of these findings especially on debt, various policy implications has emerged.

The first and foremost implication of the study is that heavy reliance on public debt must be discouraged especially in the short run. At the current rate of borrowing, Uganda is likely to have deteriorating economic growth figures partly because it adversely affects investment. Ensure efficient use of borrowed funds. The results revealed that in the long run, the public debt will bring consulate benefit to the economy thereby contributing positively to GDP. Therefore, policymakers should use these resources in a more efficient way. Priority should be given to only such projects that have the potential to unlock Uganda's productivity challenges.

The population growth rate variable has shown a negative impact on economic growth in the short run but with a positive impact on the economy in the long run. It should be noted that Uganda has one of the youngest populations in the world with almost 70\% of the people for fewer than 20 years. Therefore, there should be a good plan to cater to the population; otherwise, the country might fail to leverage from the benefits of a youthful population especially in short run. There is a need for skill development initiatives enhanced with timely technological advancement to enable the young population to contribute positively to the economy especially in long. To leverage from benefits of international trade, Uganda needs to undertake export-oriented policies that will ensure value addition on the locally produced commodities in order to fetch considerable forex. This is supported by the results from the study showing a negative impact of trade openness on Uganda's economic growth in the short run. Therefore, the issue of value addition is timely if Uganda is to benefit from international trade.

Acknowledgements

We extend our sincere gratitude to the staff who provided the technical input and review of the concept and the draft paper at the SPEED Project, National Planning Authority and Uganda Debt Network. We also thank all fellow students of PhD in economics at Makerere University class of 2018/19 for the support, and sympathy provided that made it possible to produce this output. 


\section{Authors' contributions}

SR is the main author of the manuscript; he initiated the research idea, undertook a literature review, developed the theoretical framework, collected and analyzed the data from the different sources. SK and OT are co-authors of this manuscript. They approved the research idea, supported the theoretical underpinning of the research paper, undertook quality assurance and supported the empirical data analysis and generation of policy implications. All authors read and approved the final manuscript.

\section{Authors' information}

SR is a Knowledge Management Officer-SPEED Project Makerere University School of Public Health with bias in Health economics, Development economics, Macroeconomics, Econometrics and Knowledge translation. SK is a Senior Development Planner at the National Planning Authority of Uganda and a Ph.D. in Economics student at Makerere University Kampala. He is a young professional in research with a strong bias in Monetary and Labour Economics while OT is a seasoned research fellow and holds a Ph.D. in Economics, and he is currently working as the Senior Economist at The Sustainable Development Goals Center for Africa (SDGC/A).

\section{Source of funding}

Not available.

\section{Availability of data and materials}

This study covered the period 1980-2016 and it used secondary annual data. Data on economic growth and Real interest rate were sourced from Bank of Uganda accessible at https://www.bou.or.ug/bou/rates_statistics/statistics.html while data on Human Capital Development, Gross capital formation, debt service and debt to GDP ratio were sourced from World Development Indicators (WDI) CD-ROM accessed at https://data.worldbank.org/country/uganda?view. But data on Population were sourced from Uganda Bureau of Statics accessible at https://www.ubos.org/explore-statistics/ statistical-datasets/2468/. However, all data analyzed during this study are available on request from the corresponding author.

\section{Competing interests}

The authors declare that they have no competing interest in this publication.

\section{Author details}

${ }^{1}$ Makerere University School of Public Health, Kampala, Uganda. ${ }^{2}$ National Planning Authority, Kampala, Uganda. ${ }^{3}$ Sustainable Development Goals Center for Africa (SDGC/A), Kigali, Rwanda.

Received: 9 April 2019 Revised: 10 March 2020 Accepted: 17 July 2020

Published online: 27 July 2020

\section{References}

Abbas A (2005a) Public Debt Sustainability and Growth in sub-Saharan Africa: The Role of Domestic Debt", GDN Project on the Macroeconomics of Low-Income Countries. "Public Domestic Debt and Economic Growth in Low-Income Countries. Mimeo, Department of Economics, Oxford University, New York

Abbas, S. M. (2005) "Public Debt Sustainability and Growth in Post-HIPC Sub-Saharan Africa: The Role of DD" Paper for GD Net's 2004/05 project on Macroeconomic Policy Challenges of Low-Income Countries

Abbas SA, Christensen MJ (2007) The role of domestic debt markets in economic growth: an empirical investigation for low-income countriesand emerging markets, vol No. 7-127. International Monetary Fund

Adam CS, Bevan DL (2005) Fiscal deficits and growth in developing countries. J Public Econ 89(2005):571-597

African Economic Outlook (2018): https://www.afdb.org/en/news-and-events/african-development-banks-economicoutlook-shows-decline-in-regionaleconomies-17937

AFRODAD African Forum and Network on Debt and Development (2013) Owning the loan—The Case of Uganda study report

Agénor P-R, Montiel P (1996) Development Macroeconomics. Princeton University, Princeton

Ayres RU, Warr B (2002) Economic growth models and the role of physical resources. In: Bartelmus P (ed) Unveiling wealth: on money, quality of life, and sustainability. Springer, Dordrecht

Banerjee A, Dolado JJ, Mestre R (1993) ECM tests for cointegration in a single equation framework. Oxford University Press, Oxford

Bank of Uganda (2017) State of economy Report

Buchanan, J. M. (1958), Public Principles of the Public Debt, Homewood, Illinois

Burhanudin MDA, Muda R, Nathan SBS, Arshad R (2017) Real effects of government debt on sustainable economic growth in Malaysia. Journal of International Studies 10(3):161-172. https://doi.org/10.14254 /2071-8330.2017/10-3/12

Casadio P, Paradiso A, Rao BB (2012) Estimates of the steady state growth rates for some European countries. Econ Model 29(4):1119-1125. https://doi.org/10.1016/j.econmod.2012.03.018

Cecchetti SG, Mohanty MS, Zampolli F (2010) The Future of Public Debt: Prospects and Implications. BIS Working Papers No. 300, Basel: Bank for International Settlements

Chongo BM (2013) An econometric analysis of the impact of public debt on economic growth: the case of Zambia; A Dissertation Submitted to the University of Zambia in Partial Fulfilment of the Requirement for the Degree of Master of Arts in Economics

Dasgupta D (2010) Modern Growth Theory. Oxford University Press, Oxford, pp 67-68. https://doi.org/10.1016/j. iimb.2012.01.002 
Dereje Abera Ejigayehu (2013). The Effect of External Debt on Economic growth: Department of economics Magisteruppsats 30 hp | Vårterminen 2013

Diamond PA (1965) National debt in a neoclassical growth model. Am Econ Rev 55:1126-1150

Dixit A, Pindyck R (1994) Investment under uncertainty. Princeton University Press, Princeton

El-Mahdy AM, Adel NM (1999) Public debt sustainability \& economic growth in Egypt. J Commerc Stud Res 19(1):21-55

Elmendorf D, Mankiw N (1999) Government Debt.In: Taylor JB, Woodford M (eds) Handbook of macro Economics, Vol.1, Elsevier science, B.V 1615-1699

Empirical Investigation for Low Income Countries and Emerging Markets. IMF working Paper No. 07/127, International Monetary Fund, Washington, D. C

Gujarati DN (1995) Basic econometrics, 3rd edn. Tata McGraw Hill Publishing Company Limited, New Delhi Hassan MH and Akhter T, Impact of Public Debt Burden on Economic Growth: Evidence from Bangladesh (December 1,

2012). Journal of Finance and Banking, Vol. 10, No. 1 \& 2, June-December 2012, University of Dhaka, Bangladesh Kumar M, Woo J (2010), Public debt and growth, IMF Working Paper 10/174

Laurenceson J, Chai JCH (2003) Financial reforms and economic development in China. Edward Elgar, Cheltenham, pp $1-28$

Mankiw NG, Romer D, Weil DN (1992) A contribution to the empirics of economic growth. Q J Econ 107(2):407-437

Meade JE (1958) Is the national debt a burden?. Oxford Economic Papers, New Series, Oxford

Ministry of Finance planning and Economic Development (2017) Public debt, Guarantees, and other financial liabilities report for FY 2017/18,

Modigliani F (1961) Long-run implications of alternative fiscal policies and the burden of the national debt. Econ J 71(284):730-755

Muinga RM (2014) External Public Debt and Economic Growth in Kenya, Research Paper Submitted to the School of Economics in Partial Fulfillment of the Requirements for th Award of the Degree of Master of Arts in Economics of the Unversity of Nairobi

National Planning Authority (NPA) (2010) Uganda Vision 2040

Ouattara B (2004) The Impact of Project Aid and Programme Aid on Domestic Savings: A Case Study of Côte d'Ivoire. Centre for the Study of African Economies

Oxfam (2016) who is growing; Ending inequality in Uganda, A study of the drivers of inequalities in Uganda. 333

Pattillo C, Poirson H, and Ricci L (2002), External Debt and Growth, IMF Working Paper

Pesaran HM and Shin Y (1995) "Autoregressive Distributed Lag Modelling Approach to Cointegration Analysis", DAE Working Paper Series No. 9514, Department of Applied Economics, University of Cambridge

Pesaran MH, Shin Y (1997) An autoregressive distributed lag modelingapproach to cointegration analysis. University of Cambridge, England

Pesaran HM, Shin Y, Smith RJ (2001) Bounds testi approaches to the analysis of level relationships. J Appl Econ 16:289-326 Research Journal of Finance and Economics ISSN 1450-2887. Issue 20 (2008)

World Development Report 2015: Mind, Society, and Behavior. World Bank Headquarters C Building 1818 H Street NW Washington, D.C.

\section{Publisher's Note}

Springer Nature remains neutral with regard to jurisdictional claims in published maps and institutional affiliations.

\section{Submit your manuscript to a SpringerOpen ${ }^{\circ}$ journal and benefit from:}

- Convenient online submission

- Rigorous peer review

- Open access: articles freely available online

- High visibility within the field

- Retaining the copyright to your article

Submit your next manuscript at $\boldsymbol{\nabla}$ springeropen.com 